\title{
台北市における大規模積層集合住宅の住戸平面構成
}

一台北市における大規模積層集合住宅に関する研究 その 3 -

\section{THE DWELLING UNIT PLAN OF THE LARGE-SCALE MULTISTORY APARTMENT BUILDING IN TAIPEI CITY \\ -Study on the large-scale multistory apartment building in Taipei city Part 3-}

朱 政 徳, 李 宗 翰**, 菊地吉信***, 桜井康宏****

Chengte CHU, Tzonghann LI, Yoshinobu KIKUCHI

and Yasuhiro SAKURAI

\begin{abstract}
As the sequel of a series of the study, this paper analyzes the dwelling unit plan of the multistory apartment building in Taipei City. The main conclusions are as follows.

1. There is a rough tendency that the larger the dwelling unit scale is, the more the separation between the public room and the private room comes to stand out.

2.Securing of privacy in the dwelling unit has been aimed though a basic frame of the public/private room plan is kept.

3.It can be thought about the relation between the public and the private sector that the public sector intensively promotes the improvement of the living environment from 1970's to 1980 's and the private sector advanced a rapid diversification in 1990's.

4. The transition of the building form also contributes to the environmental enhancement in the dwelling unit and the diversification of the unit plan.
\end{abstract}

Keywords : Dwelling Unit Plan, Public/Private Room, Multistory Apartment Building, Unit of Building, Taipei City 住戸平面、公・私室、積層集合住宅、住棟ユニット、台北市

\section{1. 研究の目的と方法}

本稿を含む一連の研究では, 台北市における積層集合住宅の, 1970 年代以降 30 年間の展開過程を明らかにすることを目的としている。 前々稿注1〉では, 台湾における主な住宅施策の変遷と台北市の位置 ぶけを整理し，住宅供給動向にかんする基本指標を分析した。

そして前稿拄2)では, 台北市における大規模積層集合住宅の住棟配 置, 住棟形態, 住棟ユニット形態の空間構成上の特徽を分析した注3)。 その結果, 住棟そのものは小さく高くなる方向へ収敛し, その一方で 戸外空間の多様化が進んだことが確かめられた。またこうした変化 が公共（国民住宅）では1980年代前半から徐々に進行してきたのに対 し，民間では 90 年代に急激に進展していることも明らかになった。 前稿に引き続き, 本稿では大規模積層集合住宅の住戸平面に着目し， その特徵ならびに変遷を明らかにすることを目的とする注4)

台湾における集合住宅の住戸平面について計画的視点から分析した 既往研究は多くない。前々稿でも举げたが, 主なものとして日本では 青木正夫・郭永傑等による都市集合住宅の平面と住まい方にかんする 研究注5), 江上徹・䞦明修等による国民住宅の住まい方にかんする研究 注8), そして菆志高・筆者等による住宅雑誌に掲载された住宅平面の分 析注7)，等がある。また台湾国内においては，国民住宅にかんする陳啓 名注8) や唋婜青注9)による研究があるものの，限られた資料や事例に基
づく分析にとどまっている感は否めない。

それら先行研究に対して, 本研究の独自な点としては次の 2 点を 挙げることができよう。一つには，本研究は既往研究と異なり台北 市における過去 30 年閒に供給された大規模積層集合住宅団地を網羅 的に扱い，時間軸に視点を置いて分析する点である。またもう一つ は, 公共・民間の両供給主体の比較検討を通して総合的な展開過程 を分析する点である。

本稿では, 前稿までと同様に, 分析の対象は 1971 年から 2000 年ま での 30 年間に䇋工した国民住宅と民間分譲住宅のうち, 敷地面積 3000 $\mathrm{m}^{2}$ 以上の団地である。その竝工図から基淮階平面を抽出し，基準階平 面に含まれる住戸を分析対象とした注10)。有効サンプル数は表 1 に示す ように公共 4985 戸，民間 4812 戸，合計 9797 戸である。

\begin{tabular}{|c|c|c|c|c|c|c|}
\hline \multirow{2}{*}{ 供給主㑣 } & \multirow{2}{*}{ 年代 } & \multicolumn{2}{|c|}{ 団地数 } & \multicolumn{3}{|c|}{ 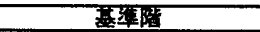 } \\
\hline & & 全体 & 䈐効数 & 住㩰数 & エニット效 & 住戸数 \\
\hline 公 & $\begin{array}{c}70 \text { 年代 } \\
80 \text { 年代 } \\
90 \text { 年代 } \\
\text { 暗 }\end{array}$ & $\begin{array}{r}18 \\
59 \\
47 \\
124\end{array}$ & $\begin{array}{r}16 \\
59 \\
47 \\
122\end{array}$ & $\begin{array}{r}57 \\
288 \\
211 \\
556\end{array}$ & $\begin{array}{r}172 \\
790 \\
435 \\
1397 \\
\end{array}$ & $\begin{array}{r}868 \\
2573 \\
1544 \\
4985\end{array}$ \\
\hline 民間 & $\begin{array}{c}70 \text { 年代 } \\
80 \text { 年代 } \\
90 \text { 年代 } \\
\text { 部 } \\
\text { 訐 }\end{array}$ & $\begin{array}{r}76 \\
90 \\
119 \\
285 \\
409\end{array}$ & $\begin{array}{r}75 \\
83 \\
114 \\
272 \\
394 \\
\end{array}$ & $\begin{array}{r}237 \\
235 \\
263 \\
735 \\
1291 \\
\end{array}$ & $\begin{array}{r}823 \\
791 \\
414 \\
2028 \\
3425 \\
\end{array}$ & $\begin{array}{l}1849 \\
1738 \\
1225 \\
4812 \\
9797\end{array}$ \\
\hline
\end{tabular}

\footnotetext{
* 台湾中原大学室内設計科 助理教授 $\cdot$ 工博

** 福井大学大学院工学研究科 大学院生

*** 福井大学大学院工学研究科 助手. 工博

**** 福井大学大学院工学研究科 教授. 工博
}

Assistant Prof., Department of Interior Design, Chung Yuan Univ., Dr. Eng. Graduate Student, Graduate School of Eng., Univ. of Fukui Assoc. Researcher, Univ. of Fukui, Dr. Eng. Prof., Graduate School of Eng., Univ. of Fukui, Dr. Eng. 


\section{2. 住戸規模の推移}

はじめに住戸専用面櫝注11) の推移を図 1 にみる。なお，面積の単位 は台湾で一般的に用いられている「坪」(1坪

公共の場合, 70 年代前半には [14 坪以下 $]$ の割合が 8 割を占め圧倒 的に多いが，80年代になると国民住宅政策の変化もあり [20～24 坪] の割合が約 5 割にまで高まり 90 年代には全体の 6 割を占めるように なった注12)。次いで [25〜29 坪］が 3 割弱を占めている。

一方，民間の場合は，70年代には [20〜24 坪] が 4 割と高いが， 80 年代にはかわって [25〜29 坪] の割合が高まり 4 割を占め, 30 平以 上の割合も増した。また， 90 年代には [25〜29 坪］［20～24 坪］が ともに 2 割を占めつつ 20 坪末満と 35 坪以上の割合の双方が上昇した。

つまり，公共の場合は70年代には極めて小規模な住戸に集中してい たが，80年代以降は [20〜 24 坪] を中心に 20 坪台が大半を占めるよ うになった。その一方で，民間ではより多様な面積規模の住宅が供給 されてきている。

\section{3. 住戸平面の類型化}

既に知られているように，台湾における分蛽集合住宅の供給は「2 段階方式」が多く採用されており, 第1段階では, 建設業者によって 躯体と間仕切り壁・床・設備（キッチン・バス・トイレ等）によって 基本的な「住戸平面（第 1 段階平面）」が構成され，第 2 段階では，購 入者 (居住者) 自身が独自にインテリア業者に依頼し，壁面・床面・ 空面への内装・家具取り付けと，場合によっては第 1 段階平面の大幅 改修も合わせて内部空間を完成させている（第 2 段階平面）。

一方，台湾における集合住宅の住戸平面は，客庁（リビング）と餐 庁（ダイニング）によって構成される「公室」を通過して「私室（各 個室)」に至る「公室通過型」が一般的であるが，上記「第 1 段階平面」 をみると, 公室と私室の関係は一様ではなく, 大きくは，視覚的（心 理的）に公室と私室が一体的に構成されるタイプ（私室のドアを開け れば公室との視覚的連続性のあるタイプ）と，廊下やアルコーヴと いった緩衝的空間を挟み私室の独立性が強いタイプに分けられる。

また，私室が一つのゾーンに集約されるタイプが大半ではあるが， 複数のゾーンに分割されるタイプもみられる。この違いは, 購入者 (居 住者）の住宅選択志向や第 2 段階平面の改修方針，さらには入居後の 生活様式（とくに公室の使われ方）に影響を与えるものと考えられる。 以上のような視点から，本研究では図 2 に示すように住戸平面を「公 室と私室の接続関係注13)」と「私室ゾーンの配置注14)」という2軸によっ て6タイプ (「フリー」タイプを含めて7タイプ）に類型化した注15)。

この結果, 公共では $[\mathrm{A} 1$ : 公私分離・集約型 $]$ が 6 割を占め, $[\mathrm{B} 1$ : 一部一体・集約型と「フリー」の3タイプで大半となるのに対して, 民間では [B1：一部一体・集約型］37\%，[Al：公私分離・集約型 $] 31$ \%を中心としながらも，[C1：公私一体・集約型] 15\%，[B2：一部一 体・分割型 $] 7 \%$, [C2 : 公私一体・分割型 $] 6 \%$ など相対的に多様な住 戸平面に分散している。

これを年代別・専用面積別に示したものが図 3 である。公共の場合， 70 年代に最も多い [14 坪以下] では [フリー] が 9 割以上を占め, 比 較的小規模なワンルーム型の住戸であると考えられる。15２4 坪の住 戸平面は [フリー $]$ に加えて $[\mathrm{Cl}:$ 公私一体・集約型 $]$ が多くなる。 80 年代と 90 年代に中心となる 20 坪台では $[\mathrm{Al}$ : 公私分離・集約型 $]$ の

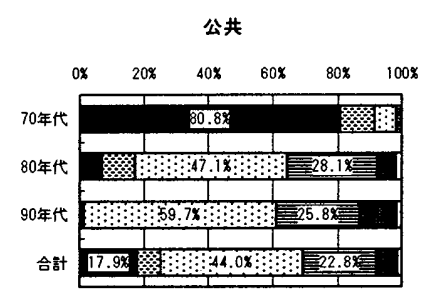

民咸

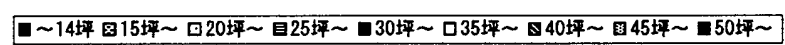

図 1 時期別にみた住戸専用面積の推移

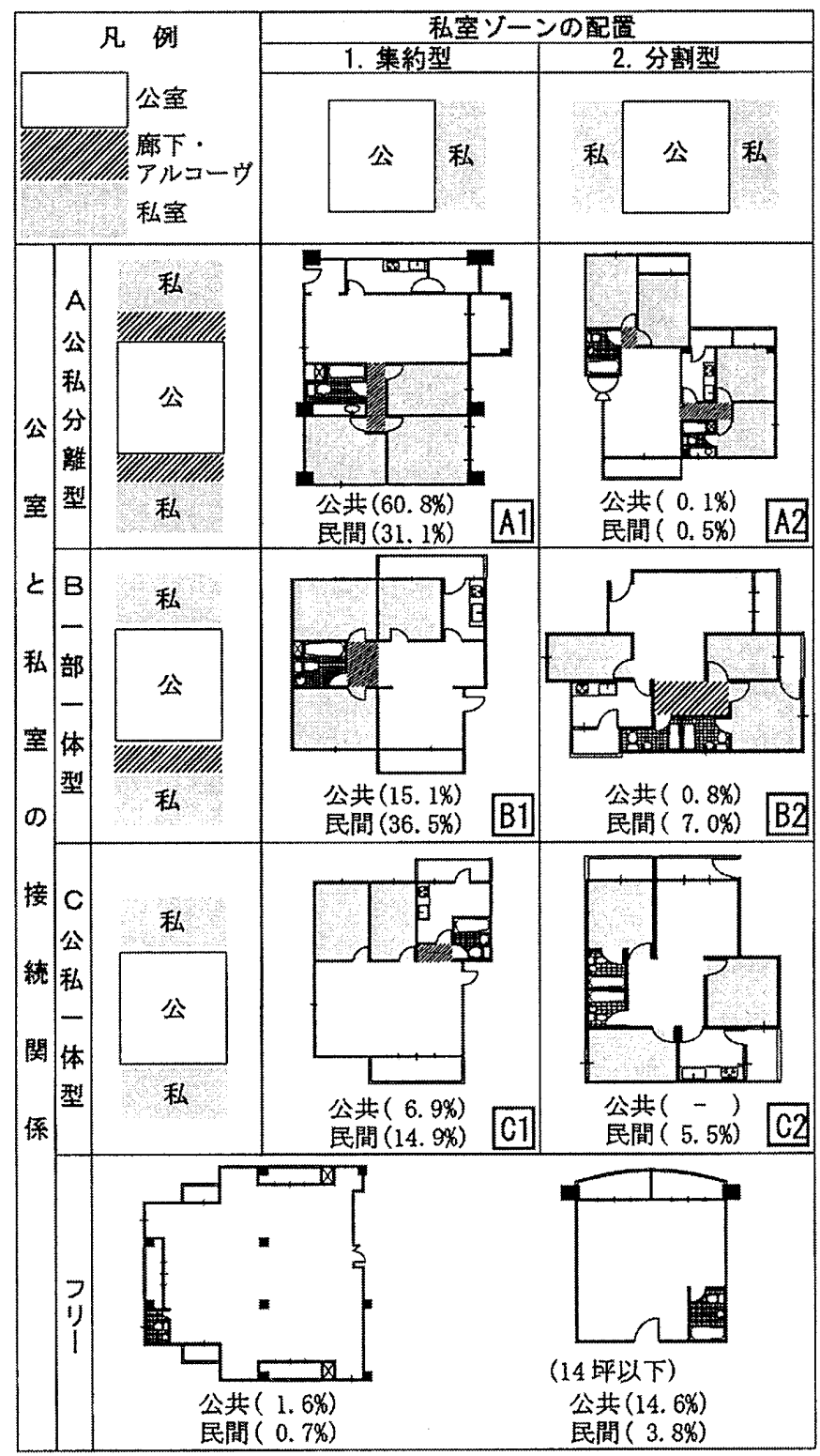

図 2 住戸平面タイプの分類

割合が $6 〜 7$ 割と非常に高い。また，25 坪以上の面積帯では $[\mathrm{B}]$ : 一 部一体・集約型〕の割合が高くなっている。

一方，民間は 70 年には 20 坪台で $[\mathrm{B} 1:$ ：一部一体・集約型 $]$ が $5 \sim 6$ 割を占め最も高い。しかし，80 年代と 90 年代には中心的な 20 坪台で [B1：一部一体・集約型 $]$ の割合が下がり，[Al : 公私分離・集約型 $]$ の 割合が高くなっている。また，公共と比べて A1 やB1 以外のタイプの 割合が高く，より多様性ある構成であることが窥われる。 

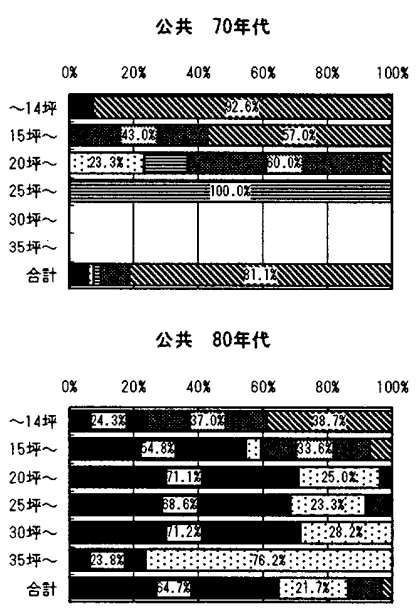

公共 90 年代

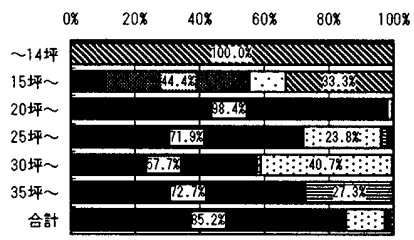

公共全体

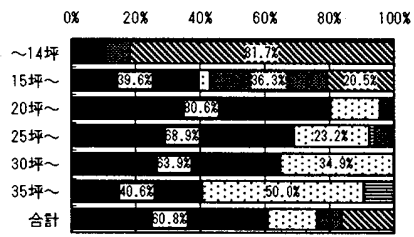

民的 70 年代

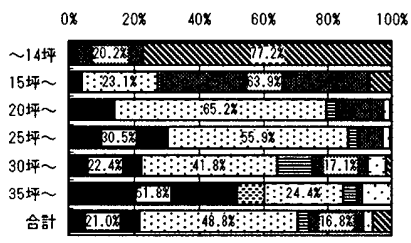

民阳 80 年代

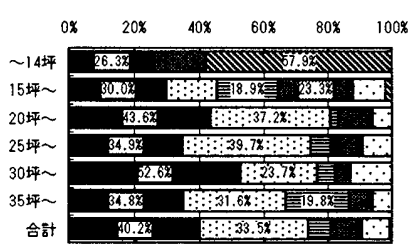

民间 90 年代

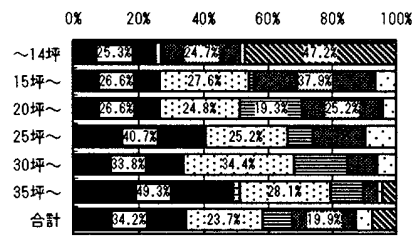

民间全体

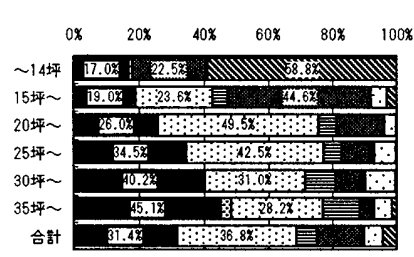

合部

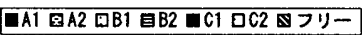

図3専用面積別に見た住戸平面タイプの推移

全体として, 住戸面積 [14 坪以下］で平面タイプ [フリー］が多い のはワンルーム型の住戸がほとんどであり，[15〜19 坪]では公・私 室が直に接する $[\mathrm{Cl}$ : 公私一体・集約型 $]$ が多く, 20 坪以上になると 公・私室の間に廊下やアルコーヴのある $[\mathrm{Al}$ : 公私分離・集約型 $][\mathrm{B} 1$ ： 一部一体・集約型］が中心となる。また，20 坪以上の面積帯では，公 共は床面積が広くなるほど [B1：一部一体・集約型］の割合が高まる のに対して，民間では $[\mathrm{A}]$ ：公私分離・集約型］の割合が高まる。

一方，私室ゾーンの配置 [2：分割型] は公共にはほとんどみられ ず，民間でも全体の約 1 割を占めるに過ぎないが，25 坪以上で相対的 に多くなっている。これは民間の中規模以上住宅における余剩室的個 室（応接・書斎・家事室・趣味室等）の存在を窥わせる。

また，[14 坪以下] では [フリー] が多いのに対して [15〜19 坪] では $[\mathrm{Cl}$ : 公私一体・集約型 $]$ の割合が高くなる。 $[\mathrm{Cl}$ : 公私一体・集 約型］の割合は民間のほうが公共よりも高く, 民間では 20 坪以上の面 積帯でも一定の割合を示すものの面積が広くなるにつれて減少する。 かわって公共では $[\mathrm{Al}:$ 公私分離・集約型 $]$ が，民間では $[\mathrm{Bl}:$ 一部 一体・集約型］が中心的な住戸タイプとなる。

\section{4. 住戸平面と住棟ユニット形態との関係}

まず，前稿でも分析した住棟ユニット形態注16) と住戸プランの関係 を分析するために, 住棟ユニットのうち全体に占める割合の高い「廊

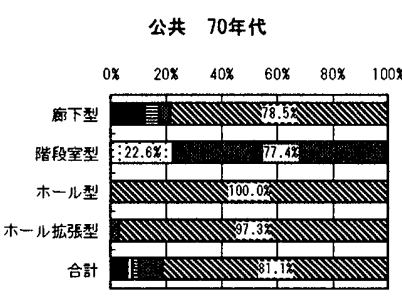

公共 80 年代

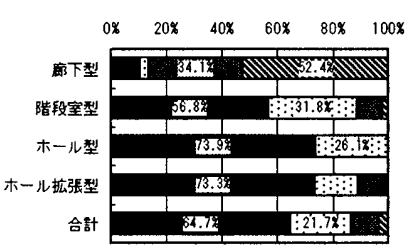

公共 90 年代

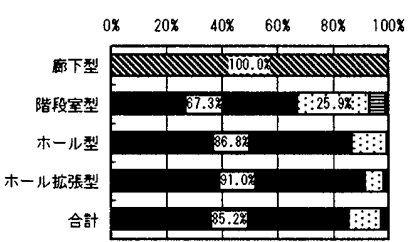

公共 全体

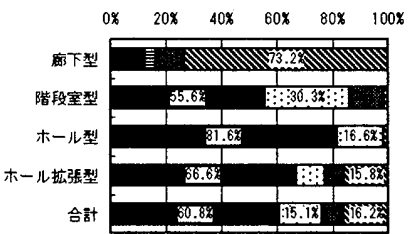

民咸 70 年代

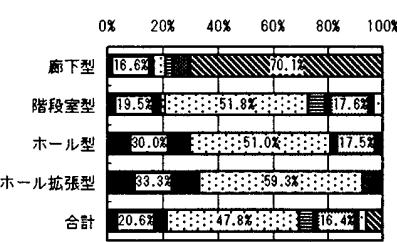

民的 80 年代

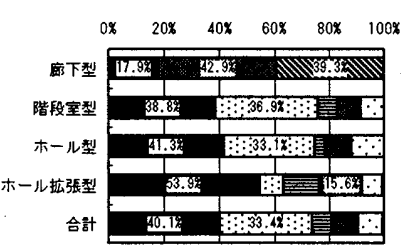

民成 90 年代

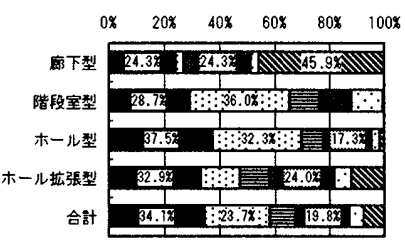

民间全体

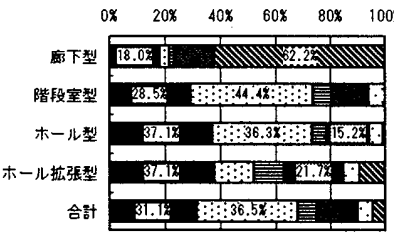

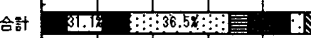

\section{A1 QA2 -B1 目B2 日C1 QC2 \&フリ-}

因 4 住棟ユニット形態別にみた住戸平面タイプの構成

下型」「階段室型」「ホール型」「ホール拡張型」の4タイプに注目する。 なお，前稿によれば，公共は 70 年代には廊下型ユニットが多かった が時間とともにホール型ならびにホール拡張型ユニットへとシフトし た。一方，民間は廊下型ユニットが極めて少なく, 70 年代, 80 年代と もに階段室型ユニットが大部分であったが, 90 年代にホール型・ホー ル拡張型ユニットが急增した。

図 4 により住棟ユニット形態と住戸プランの関係についてみると, まず全体としては，前節で述べたとおり公共では $[\mathrm{A} 1$ ：公私分離・集 約型]，民間では [B1：一部一体・集約型］の割合がそれぞれ比較的高 いのが特徴である。そして, 公共では, 70 年代には階段室型が $[\mathrm{C} 1$ : 公私一体・集約型 $]$ と [B1：一部一体・集約型 $]$ で占められている点 を例外として，ほぼ全てが [フリー］タイプである。80年代は廊下型 に [フリー $]$ と $[\mathrm{Cl}:$ 公私一体・集約型 $]$ が残される点を例外として, その他のタイプでは $[\mathrm{A} 1$ : 公私分離・集約型 $]$ と $[\mathrm{B} 1:$ ：部一体・集 約型 $]$ が主要となり始める。そして 90 年代には, 廊下型は全てが [ リー］であるが, その他のタイプでは [A1 : 公私分離・集約型 $]$ の比 重が一層高まっている。一方の民間は, ホール拡張型において70年代 には [B1：一部一体・集約型 $]$ が 6 割を占めていたのが 80 年代以降大 きく減少し，その他のタイプ（80 年代にはとくに $[\mathrm{A1}], 90$ 年代には とくに $[\mathrm{Cl}]$ と [フリー]) に分散している点を除いて, 各タイプとも 大きく変化はしていない。 


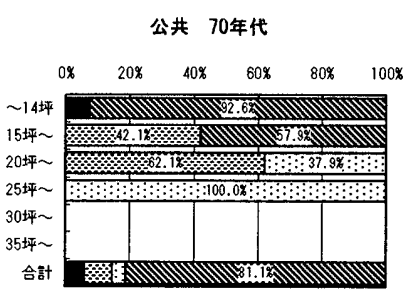

公共 80 年代

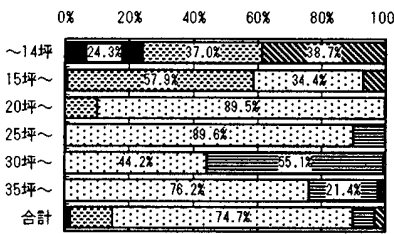

公共 90 年代

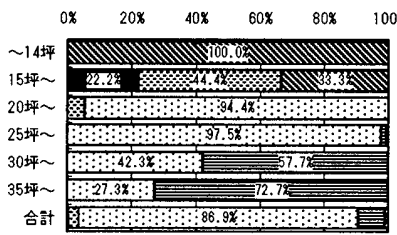

公共 全体

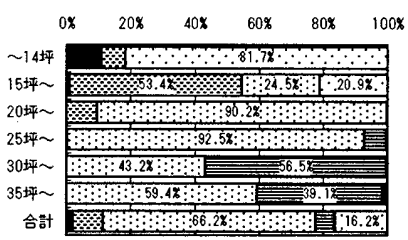

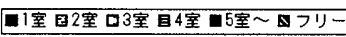

图 5 専用面積別にみた個室数の推移

\section{5. 住戸平面の特徵}

ここでは，個室数に加えて，台湾の住戸形式の特性を表す代表的指 標としてエントランス形式，バスユニット数，開口面数（1室あたり 開口面数）を検討する。

\section{5-1. 個室数}

個室数の分類は，壁によって区切られた室数によって［1 室］［2室］ ［3 室］４４室］５室＜wide>]に分類し，前節と同様に1住戸内に区切られた 個室がなくオープンな間取りのものを [フリー］とした。

図 5 により，まず各年代の合計をみると，公共の場合は 70 年代には [フリー］が 8 割を占めており最も多いが，80年代には [3室] が6 割 を占めるようになり，90 年代には [3 室］は 9 割を占めている。

一方，民間は 70 年代から 80 年代にかけて [3 室］を中心に [2 室］ から［4室］まで幅広く分布しているが，90年代には［4室］が急增し て 3 室未満と 4 室以上への分化傾向がより顕著となっている。

次に，先述の図 1 も合わせて専用面積別にみてみると，公共では尃 用面積が应大するのに伴い室数も增えてきた。たとえば， 70 年代に最 も多い [14 坪以下] では [フリー] が 9 割を占める。一方で $[20 \sim 24$ 坪］では [2 室]，[25〜29 坪］では [3 室］の割合がそれぞれ高い。8 年代に多い 20 坪以上では [3 室] の割合が高まるが，90年代になると 20 坪台は［3 室］の割合が高いものの，30 坪以上では［4室］が過半 を占めるようになる。

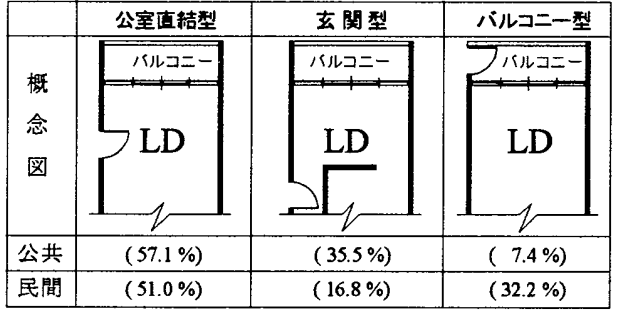

図 6 エントランスタイプの模式図
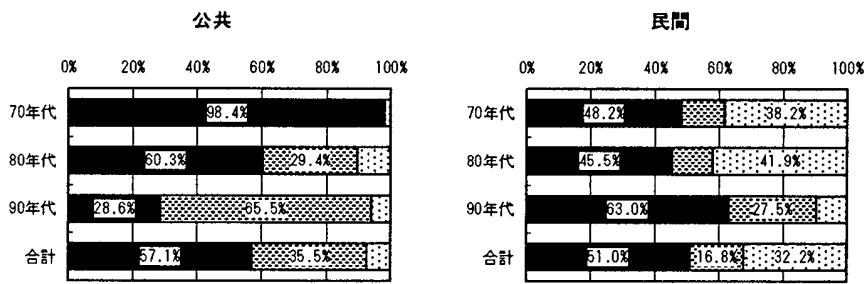

日公至直緯型の玄関型曰バルコニー型

図 7 時期別にみたエントランスの推移

一方，民間では， 70 年代の [14 坪以下］は公共と同様に [フリー が中心となっているが，80年代以降その割合は低下しつつあり [1 室 ] と [2 室 $]$ の割合が徐々に高くなってきた。90年代には両方を合わせ て5割を占めている。さらに, [15〜19 坪] では [2 室］の割合が高 いが，90年代になると 20 坪台の [3 室］と 30 坪以上の [4室］タイプ が高い割合を占めている。

以上より，公共と民間の共通点としては，[14 坪以下］は [フリー]， [15〜19 坪]は [2 室]，20 坪台は［3 室］がそれぞれ主流であるが， 30 坪を境として $[4$ 室］の割合が高まる。また，上述のとおり民間で は 80 年代から 90 年代にかけて住戸面積構成が多様化する中, 個宣数 は増加の傾向を示している。

\section{5-2. エントランス}

日本にはみられない台湾の住戸平面の特幑の一つに「エントランス」 の形式がある注17)。その実態は，図 6 に示すように，(1外部から直接 「公室」につながる [公室直結型]，(2)壁などに区切られた緩衝的空間 を経由する [玄関型]，(3)バルコニーから「公室」に入る[バルコニー 型］の3タイプに分けられる。全体として公共・民間ともに [公室直 結型]が $5 \sim 6$ 割を占め，次いで公共は [玄関型]，民間は [バルコニー 型]がそれぞれ多い注18)。

図 7 をみると，公共では，70 年代には [公室直結型］の割合が極め て高く $98 \%$ を占めるが，80年代以降 [玄関型] の割合が上昇し，90年 代には 6 割以上を占めている。一方，民間では，70，80 年代には [公 室直結型］が 5 割弱, [バルコニー型］が 4 割弱と二分されているが, 90 年代には [バルコニー型] の割合が低下し，[公室直結型］の割合 が 6 割に上昇するとともに [玄関型］も約 3 割を占めている。

\section{5-3. バスユニット数}

バスユニットを複数簓所に有する点も日本にはみられない特徴の一 つである。ここでは，その数と設置箅所を検討する。

まず，その数については，図 8 に示すように, バスタブのあるもの を 1 セット，バスタブのないものを 0.5 セットと規定し，その合計値 
を算定した注19)。

図 9 をみると, 公共では 70 年代の 1 セットから徐々に 1.5 セットお よび 2 セットの割合が高くなり，90 年代には1セットの割合が 2 割を 下回っている。また，民間では 70 年代から 80 年代には 2 セットの割 合が公共に比べて高いものの，90 年代には 1 セットの割合も增加して 二極化の様相を示している。また，全体的にみると民閒は公共よりバ スユニット数が多いことがわかる。

続いて面積の点からみると, 公共の場合, [14 坪以下] が圧倒的に 多い70年代には 1 セットの割合が圧倒的に高い。80年代になると面積 の増加に伴いバスユニット数も増え，90年代には 19 坪以下では 1 セッ ト, 20 坪台は $1.5 セ ッ ト, 30$ 坪以上では 2 セットと, 面積によりユニッ 卜数が明らかに異なる。

一方，民間では 19 坪以下では 1 セット，30 坪以上では 2 セットがそ れぞれ最も多く, 中間の 20 坪台では 70 年代の 1 セットから 90 年代の 2 セットに推移したことが表れている。

また, 80,90 年代の 20 坪台を比較すると, 公共は 1.5 セットの割合 が最も高いのに対し，民間では 2 セットの割合が最も高い。したがっ て，この点は民間のほうが設備が充実していると言えよう。

続いて，バスユニットの設置箘所（接続先）を［公室］［廊下（アル コーヴを含む)］[個室］の 3 タイプに分類し，ユニット数ごとにその 実態を示したものが表 3 である。

70 年代, 公共では 1 セットの [公室] の割合が圧倒的に高く 9 割を 占めるのに対し，民間では 1 セットの［廊下］が 4 割弱，[公室］が 2 割強を占め，続いて 2 セットの［廊下+個室］も2 割を占めている。 80 年代になると, 公共では1セットの [公室] が 3 割に低下し［廊下］が

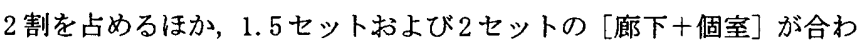
せて 4 割弱を占める。

また，民閒では1セットの [廊下] が1割に低下し，1.5および2セッ トの［廊下十個室］が合わせて $65 \%$ を占めるようになった。90年代に は，公共では 80 年代に引き続き 1.5 および 2 セットの [廊下十個室］ が合わせて 75\%に増加し，対照的に1セットの [公室]はわずかとなっ ている。また，民間では 1.5 および 2 セットの［廊下十個室］が合わ せて 5 割を占める一方，1 セットの [公室] が 2 割を占めている。

バスユニット数が複数（1.5 セット以上）ある場合，接続先は [廊 下十個室］の割合が高く，[公室十個室］がそれに続く。すなわち個室 に 1 ないし 0.5 セットが接続するのであるが，この場合の個室とは主 寝室である場合が大半である（3 セット以上になる場合は他の個室に も広がる)。つまり, 公室や廊下に複数のバスユニットを設けて世帯員
ないし来客の用に供するよりも，主寝室の利便性とプライバシ一の向 上が優先されることがわかる。

さて, 上述した時期別の推移は当然ながら住戸規模の変化とも対応 している。先に図1でみたとおり，70 年代の公共は [14 坪以下]に集 中しており，バスユニット数は 1 セットがほとんどであった。 80,90 年代には $[20 〜 24$ 坪］を中心としつつ 25 坪以上の割合も潮增し，バ スユニット数も 1.5 ないし 2 セットの割合が増加した。そして接続先 は公室から廊下へ推移してきた。

一方，民閒では，住戸規模の構成は公共に比べて多様であり，80年 代から 90 年代にかけては 20 坪以下の割合が増加している。それに伴 い,バスユニットの数も 80 年代以降は 1.5 セット以上を中心としつつ
公共 70 年代

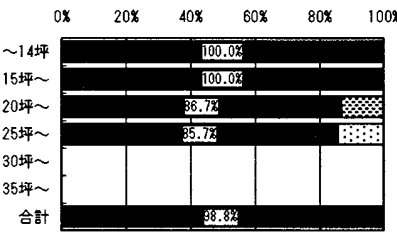

公共 80 年代

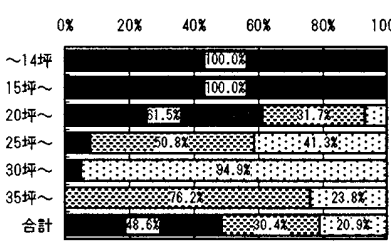

公共 90 年代

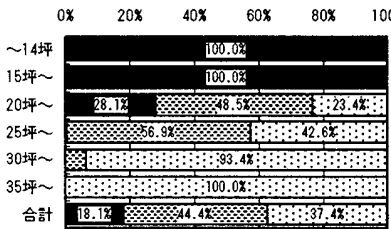

公共 全体

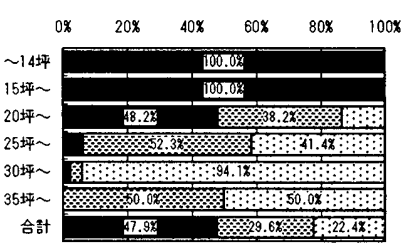

民盟 70 年代

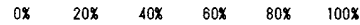

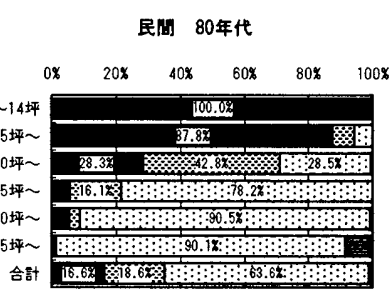

居而 90 年代

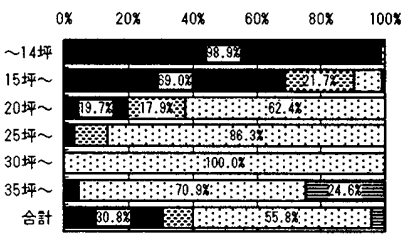

民全休

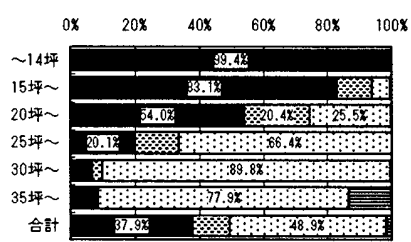

日セッット1.5セットロ2セット目2.5セット〜

图 9 専用面積別にみたバスユニット数の推移

表 3 時期別にみたバスユニットの接統先

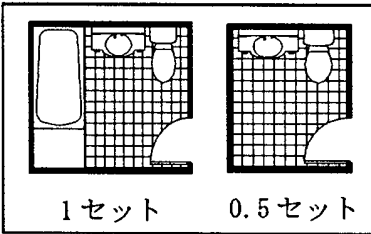

図 8 バスユニットの模式図

\begin{tabular}{|c|c|c|c|c|c|c|c|c|c|c|c|c|c|c|c|c|c|}
\hline \multirow{3}{*}{ 接槙先 } & \multirow{3}{*}{ ユニニトト数 } & \multicolumn{4}{|c|}{70 年 代 } & \multicolumn{4}{|c|}{80 年 代 } & \multicolumn{4}{|c|}{90 年 代 } & \multicolumn{4}{|c|}{ 全体 } \\
\hline & & 公 & 共 & 民 & 而 & 公 & 井 & 民 & 向 & 公 & 共 & & 高 & 公 & 共 & 民 & \\
\hline & & $n=$ & 868 & $n=$ & 1848 & $n=2$ & 573 & $n=$ & 698 & $n=1$ & 1533 & $n=$ & & $n=4$ & 1974 & & 4753 \\
\hline 奎 & $\frac{1}{1.5}$ & $92.9 \%$ & 92.95 & $26.1 \%$ & \begin{tabular}{|l|}
$23.9 x$ \\
$2.2 x$
\end{tabular} & $31.2 \%$ & 31.23 & 6. 5\% & \begin{tabular}{|l|}
$5.4 \%$ \\
$1.1 \%$ \\
\end{tabular} & $1.8 \%$ & $1.8 \%$ & $23.2 \%$ & $\frac{23.0 \%}{0.2 \%}$ & $32.9 \%$ & 32.94 & $18.4 \%$ & $\frac{77.13}{1.3 \%}$ \\
\hline 应下 & $\frac{1}{1.5}$ & $6.0 \%$ & $6.0 \%$ & $39.9 \%$ & \begin{tabular}{|l|}
$36.7 \mathrm{~K}$ \\
$3.1 \%$
\end{tabular} & $20.7 \%$ & $\begin{array}{c}20.5 \% \\
0.2 \%\end{array}$ & $11.8 \%$ & $\frac{11.5 x}{0.4 \%}$ & $18.7 \%$ & \begin{tabular}{|c|}
$16.4 x$ \\
$2.2 \%$ \\
\end{tabular} & $7.4 \%$ & $7.4 \%$ & $17.5 \%$ & $\frac{16.7 x}{0.8 \%}$ & $21.6 \%$ & \\
\hline 面 垔 & 1 & & & $2.1 \%$ & 2.18 & & & 0.28 & 0.28 & $0.1 \%$ & $0.1 \%$ & $0.7 \%$ & $0.7 \%$ & $0.04 \%$ & $0.04 \%$ & $1.1 \%$ & 1.18 \\
\hline 公空+店下 & $\frac{1.5}{2}$ & & & 1. $2 \%$ & \begin{tabular}{|l|}
$1.1 \%$ \\
0.18 \\
\end{tabular} & 3. $0 \%$ & $\begin{array}{l}0.9 \% \\
2.1 \%\end{array}$ & $2.0 \%$ & $\begin{array}{l}0.4 \% \\
1.6 \% \\
\end{array}$ & $3.1 \%$ & $\begin{array}{l}2.5 \% \\
0.6 \% \\
\end{array}$ & $2.0 \%$ & $\frac{0.28}{1.78}$ & $2.5 \%$ & \begin{tabular}{|l|}
$1.2 \%$ \\
1.28 \\
\end{tabular} & $1.7 \%$ & $\begin{array}{l}0.6 \% \\
1.1 \%\end{array}$ \\
\hline 公茥十周咅 & $\begin{array}{l}1.5 \\
2 \\
\end{array}$ & $1.2 \%$ & $\begin{array}{l}0.9 \% \\
0.2 \% \\
\end{array}$ & $7.1 \%$ & \begin{tabular}{|l|}
$0.2 \pi$ \\
$7.0 \%$ \\
\end{tabular} & 8. $2 \%$ & $\begin{array}{l}5.9 \% \\
2.2 \% \\
\end{array}$ & $16.0 \%$ & \begin{tabular}{|c|}
$2.7 \%$ \\
$13.4 \%$ \\
\end{tabular} & $2.2 \%$ & $\begin{array}{l}1.4 \% \\
0.7 \%\end{array}$ & $19.5 \%$ & $19.5 \mathrm{x}$ & $5.1 \%$ & \begin{tabular}{|l|}
$3.7 \%$ \\
$1.4 \%$ \\
\end{tabular} & $13.4 \%$ & $\frac{1.0 x}{12.4 x}$ \\
\hline 店下十调至 & \begin{tabular}{|l}
1.5 \\
2 \\
\end{tabular} & & & $23.5 \%$ & \begin{tabular}{|c|}
$3.8 \%$ \\
$19.8 \%$ \\
\end{tabular} & $36.9 \%$ & \begin{tabular}{|l|}
$19.0 \%$ \\
$17.9 \%$ \\
\end{tabular} & 63. 3\% & \begin{tabular}{|l|}
$12.6 X$ \\
$50.6 \%$ \\
\end{tabular} & 74. $2 x$ & \begin{tabular}{|l|}
$37.9 x$ \\
$36.3 x$
\end{tabular} & $46.3 \%$ & $\begin{array}{r}6.6 \% \\
39.7 \%\end{array}$ & $42.0 \%$ & \begin{tabular}{|l|}
$21.5 x$ \\
$20.4 x$
\end{tabular} & $43.5 \%$ & $\frac{7.7 \%}{35.9 \%}$ \\
\hline 公高十西 & 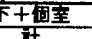 & & & $0.1 \%$ & $0.1 \%$ & & & $0.1 \%$ & $0.1 \%$ & & & $0.9 \%$ & $0.9 \%$ & & & $0.3 \%$ & $0.3 \%$ \\
\hline 含 & if & 10 & & 1 & $00 \%$ & 10 & $0 \%$ & 1 & & 10 & $00 \%$ & 1 & & $\overline{10}$ & D\% & & $\frac{10 \%}{00 \%}$ \\
\hline
\end{tabular}

注) $\square$ は10\%以上を示す。 
90 年代には 1 セットの割合が 3 割程度を占めるようになり公室接続の 割合も高くなった。

\section{5-4. 開口面数（1 室当たり開口面数）}

前稿で述べたように, 台湾における集合住宅の住棟形態・ユニット 形態は極めて多様で複雑であり，そのことが住戸の平面形態にも現れ ている。この多様な平面形態をここでは「開口面数（開口部をもつ 壁面の数)」という視点から検討する。

まず，【住戸の開口面数 $=\Sigma\left(\right.$ (各室ごとの開口面数注 $\left.{ }^{20}\right)$ )】と定義し， その実態を住棟ユニット形態別に示したものが図 10 である。

公共・民間ともに [5 面 $]$ がほぼ半数を占め, [6 面] 以上が公共で 約 2 割，民間で約 3 割となっている。住棟ユニット形態別にみると，公 共では階段室型，民間ではホール型の開口面数が相対的に多いのに対 して，廊下型は公共・民間ともに [3 面] 未満が大半で極めて少ない。 続いて, 開口面数は室数によって変化すると考えられることから, 【1 室当たり開口面数＝開口面数 $\div$ 総室数注 ${ }^{21)}$ と定義し，その実態を 年代別・私室数別に示したものが図 11 である。ここで，1 室当たり開 口面数が [1 面〜]は「全ての室の 1 面開口が確保された状態」，[1.5 面 〜] は「半分の室の 2 面開口が確保された状態」，[2面〜］は「全ての 室の 2 面開口が確保された状態」を平均的には意味している注22)。

これをみると, 公共では 2 室タイプに [1.5 面〜] がやや目立つが， 9 割以上が [1.0 面〜］となっている。これに対して民間では [1.5 面 ］ [2.0 面〜 ] 以上が約 3 割を占めており，1〜2 室タイプでは $[2.0$ 面〜］以上， 4 室以上タイプでは [1.5 面〜］の割合がとくに高くなっ ている。

年代別にみると, 公共では70 年代は 2 〜室タイプで [1.0面末満] が 3 割ほどみられ，80 年代には 2 室以上タイプで逆に [1.5 面〜] が 1 〜 2 割ほどみられるが，90 年代には [1.0 面〜］がほぼ全数となって いる。一方, 民間では, 70〜80 年代には $1 \sim 2$ 室の少室数タイプを中 心に [1.5 面〜] 以上が 1 割程度であったが，90 年代にはほぼ半数と なり，中でも 2 室タイプでは約 9 割が [1. 5 面〜］以上となっている。 また，1〜2室タイプでは [2.0 面〜］以上も 2 割を超えている。この 民間における変化は公共と大きく異なっており，90年代の民間におい ては開口の多い居室の配置を可能にするような複雑な住棟形態につな がっているものと考えられる。

6. まとめ

本稿の主な結論は以下のようにまとめられる。

(1)公共・民間ともに，住戸平面の構成は基本的に公室通過型である。 全体としては [公私分離・集約型］を中心としつつ，小規模住戸で は [公私一体型]，中規模住戸では [一部一体型]，大規模住戸では [公私分離型］がそれぞれ多いという大まかな傾向がみられる。ま

た，平面構成の多様性は民間のほうが顕著である。

(2)エントランスの特徴として，[公室直結型］を中心としつつ［玄関 型]の増加してきたことが公共と民間に共通した変化として挙げら れる。ただし，民間では 80 年代まで [バルコニー型] が根強く残さ れていた。

(3)バスユニット数 1.5 セット以上, 1 室当たり開口面数 1.5 面以上が相 当数みられるなど, 日本の集合住宅以上に居住条件を向上させてい
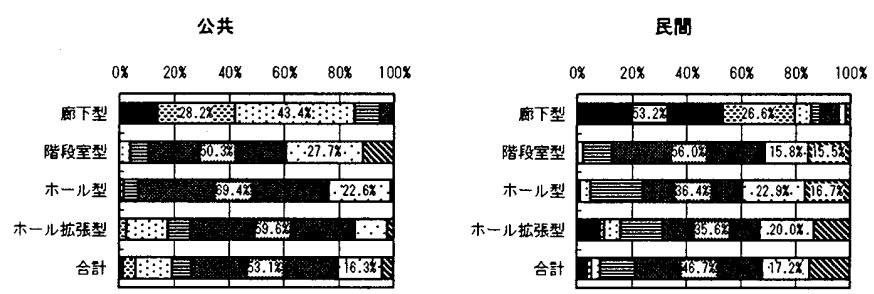

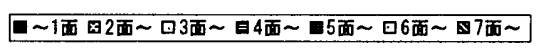

図 10 住棟ユニット形態別にみた 1 住戸当たり開口面数
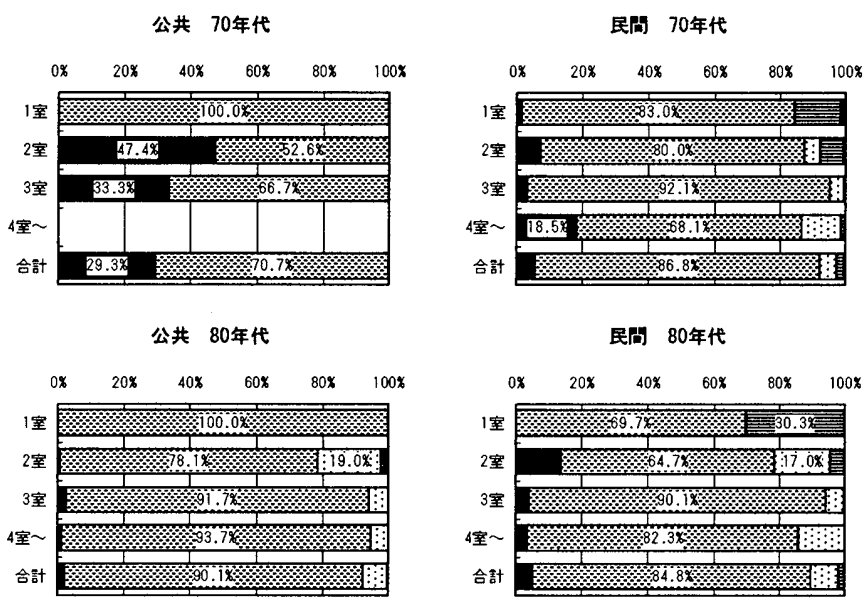

民年 80 年代

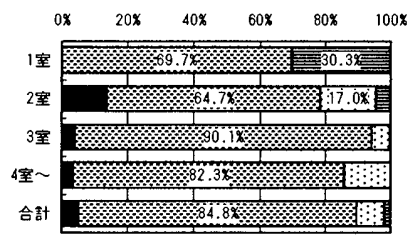

民成 90 年代
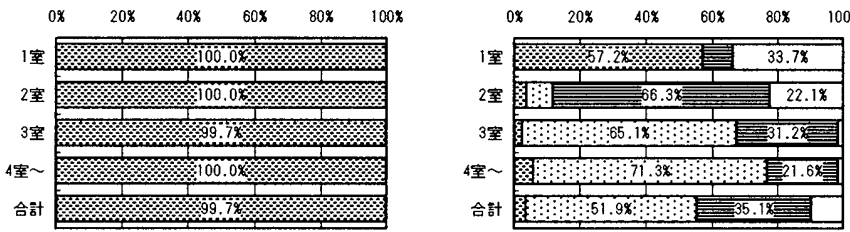

公共全体

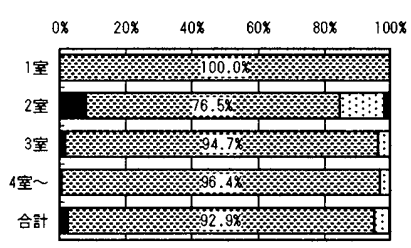

民咸 全体

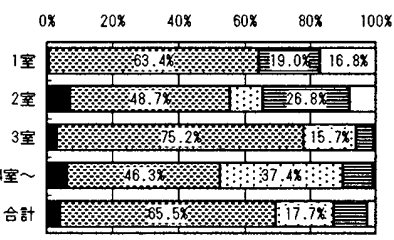

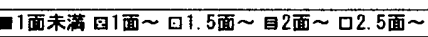

\section{図 11 個室数別にみた 1 室当たり開口面数}

ることが窥われる。

(4)すなわち，公・私室という住戸平面の基本的枠組みを残しつつも， 総合的には住戸の居住水準と設備の改善, およびプライバシーの向 上が志向されてきたとみることができ，この傾向はとくに民間にお いて顕著である。

(5)公共と民間の関係を年代別にみれば，70年代から 80 年代にかけては 公共が集中的に住宅の水準向上を押し進め，一方の民間は 90 年代に 入って規模・形態ともに急速な多様化を進めたと言うことができる。

以上の内容と前稿までの成果を踏まえて考察すると, 公共では大規 模開発・大規模住棟・大規模ユニットの条件下で地区計画的スケール で（戸外コモンスペース等一体的住環境を考慮しつつ）住戸を計画・ 
供給してきた。一方，民間では低層の比較的小規模な積層集合住宅の 経験，すなわち小規模開発・小規模住棟・小規模ユニットの条件下で, 建築計画的スケールで居住条件の改善と設備的改善を重ねてきたもの と推察される。

今後はさらに検証を重ねるとともに，公室周辺の「第 2 段階平面」 の把捏, 各住戸タイプの居住階層, 戸外コモンスペースの使われ方, について調查を継続する予定である。

\section{謝辞}

本稿の内容を含む一連の研究に対して，2006年台湾行政院国家科学 委員会の研究計画NSC-95-2221-E-033-080による助成を得た。ここに 記して謝意を表す。

注

注1)朱政徳，商聖管，菊地吉信，桜井康丢 : 台北市に抽引大規模積層集合住宅の供給実熋 一台北市に扔ける大規模積層集合住宅に開する研究 その1-, 日本建筑学会計画系 論文集, 第 569 号, pp. 161-168, 2003.7

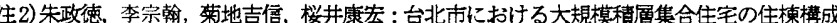
一台北市における大規模積層集合住宅に関する研究 その 2 -，日本建筑学会計画系 論文集, 第601号, pp. 17-23，2006.3

注3)一連の本研究では集合住宅の空間構成を附図 1 の上うに段階的に捉えている。

注4)本文中でも述べているように，台湾の分淁共同住宅の施工・㤨給は2段階で行われる場 合が少なくない。本稿は堎工時の図面を資料としているので、「第1段階」における住宅 平面を分析していることになる。

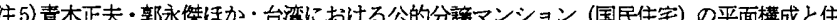
まい方 第 1 報 住宅形式及び平面構成について，日本建策学会大会学術謱演梗概集， E-2, pp. 9-10,1988. 10, 同 第2報 住まい方について, 日本建勧学会大会学術满演梗

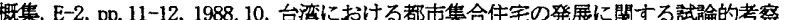
第 1 報 「透天せき」形式の平面構成の発展について，日本建勧学会大会学術講演梗概 集， E-2，pp.13-14，1988.10，同 第2報「公寓」の平面構成の発展について，日本建 筑学会大会学術講演梗概集, E-2, pp. 15-16, 1988. 10

注6)江上徹・吳明修ほか：台湾国民住宅の住戸計画の課題に関寸る研究 その1，日本建勧 学会大会学術講演梗概集, E-2, pp. 7-8, 1997.9, 同 その2, 日本建筮学会大会学術諎 演梗概集, E-2, pp. 9-10, 1997.9

注7)聶志滈・朱政徳ほか: 台湾の都市型楮層集合住宅における平面構成の供給実態，福井大 学工学部研究報告, 第 51 巻第 1 号, 2003.3

注 8) 陳啓名 : 國民住宅居住単元空間平面演化之探討, 台湾科技大学修士論文, 1982

注9)唋肇青 : 國民住宅設計準則研究, 内政部建策研究所, 1992.9

注 10)住戸形式にはいわゆるメゾネット形式や中二階をもつ皘層の住戸もあるが，本稿で フラット形式の住戸のみを分析对象とした。

注11)本稿の面積はすへてて内法寸法て測定した值である。

注12)『國民住宅社區規劃及住宅設計規則』が1984年に修正された。同規則により定められる 国民住宅の標準面積は一般住宅の場合と軍釒村改築の場合とで異なり，一般住宅は 12 $16 ， 20 ， 24 ， 28$ 坪，軍帣村 (軍人家族用居住地) 改筑は $24 ， 26 ， 30 ， 34$ 坪となっている。

注13)「公室と私富の接䌇関係」については，各平面図において「客庁 (リビング)」と「整 宁 (タイイニング)」の基本的矩形を想定し，そこに直接接続する私室を「一体型，廊下 あるいはアルコーヴ (基本的矩形と私室との間の緩衝的小矩形空間)を介して接続する 私室を「分離型私室」とし，全ての私室が分離型であるむのを「公私分離型，全ての 私室が一体型であるものを「公私一体型，一部の私室が一体型であるものを「一部一 体型の3タイプに類型化した。なお，公私室型の平面構成については，かつて米軍向 けに建設されたアメリカ式住户平面の影鄉が指摘されている(注5の青木らなど)。

注14)「私室ゾーンの配置」については，「客庁」「瞥庁」「台所」から成る公室ソーンンを想定し それたよって私室ゾーンが分割されるものを「分割型，されないむのを「集約型」の 2タイプに類型化した。なお「台所」は基本的に「餐庁」に隣接し,多くは宣接つながっ ているが，廊下あるいはアルコーヴを経てつながるケースも一部みられる。なお，LK の構成はKが独立したLDKの2室タイプが全体の8～9割を占め，LKKの1室タイプは1 〜2割程度である。これ油や煙の出る諸理が多いことに起因すると考えられる。

注15)図2に例示した各图面はいずれも公共部門（国民住宅）のものである。各住戸の面積 と建策年は次のとおりである。A1:21 坪・1998 年, $\mathrm{A} 2: 32$ 坪・1992 年, B1 : 20 坪・1984

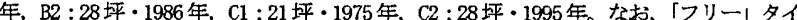
プについては, 小規模ワンルームタイプのほか, 滈額所得者のニーズに合わせるために 敢えてフリータイプとする大規模住宅も一部みられる。

注 16) 住棟ユニット形热の分類は附図2のとおりである。本文中では片廊下型・中倣下型・回 廊型をまとめて廊下型としている。また，住棟ユニット形態の構成は附図3のように推 移している。

注 17)もともと台湾では入室の際に履物を脱ぐ習慣はなかったが，日治時代以降，住生活梯 式の影響から履物を脱ぐ習慣が浸透した。エントランスに収納スペースがなく写真1の ように住戸外の共用スペースに履物を置くケースも少なくない。

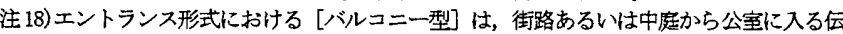
統的な形式を引き継ぐまのと推測される。それが民間部門に多くみられる点については 伝統的様式の低層集合住宅を供給してきた民間部門の習慣が大規模積層集合住宅にも反 映されたものにそれに対して公共部門は先進諸国の計画理論の影響を相対的には強く受

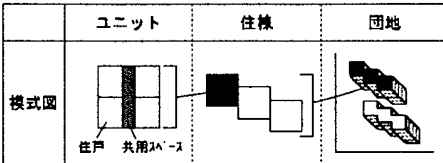

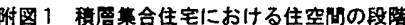
(注 2 より転野)

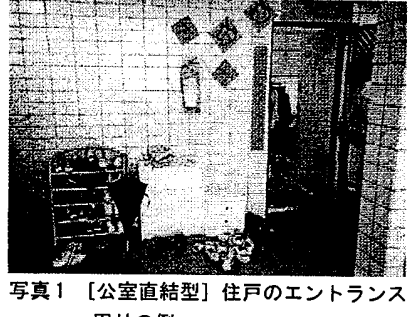

周りの例

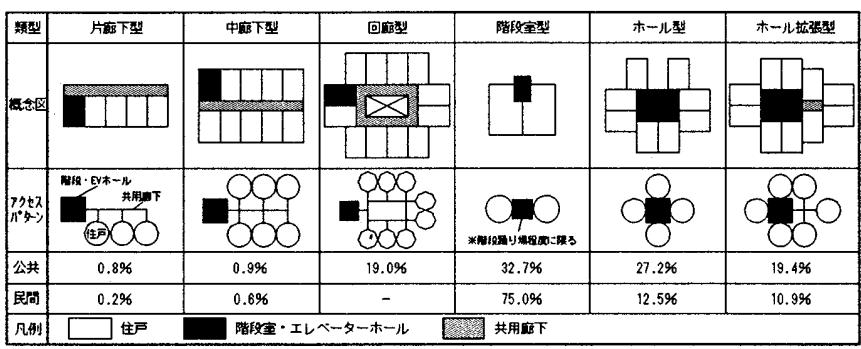

附図 2 住拣ユニット形態の分類と副合（注 2 より転载）

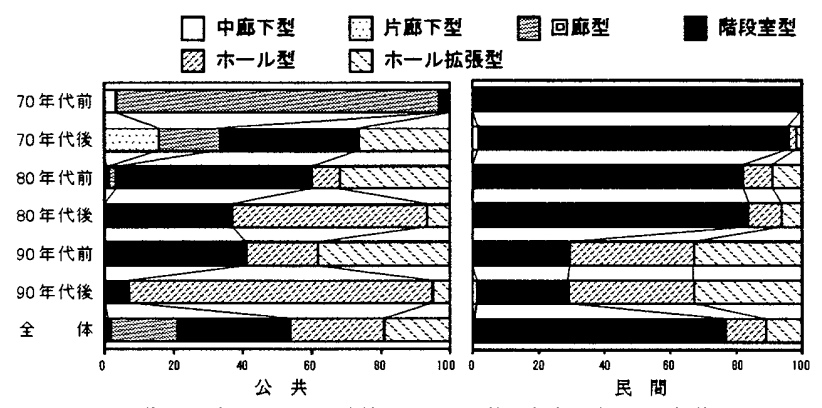

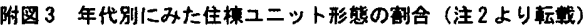

けている）と仮説的に考えているが，残念ながら確証は得られていない。今後の課題と したい。なお［バルコニー型は「階段室型1住棟ユニットにおいて多く見られ，1990年 代に民間の「階段室型]住棟ユニットが急減 (附図3参照) したことに伴い[バルコニー 型了も減少したと考えられる。

注19)バスタプのないタイプにはシャワーを有するものも含まれるが, 図面上では判然としな いもの多いためバスタブの有無によってのみ分類した。また，合計值について，1.51 $\lceil 1+0.5\rfloor$ (2力所) であるが, $2.0 k は 「 1+1\rfloor(2$ 力所) と「1+0.5+0.5」(3力所) の2通りある。本文図 2 の 2 ，B2，C2は，いずれも「1+1」の事例である。

注 20)住戸の開口面数については「公室（LD」）と「独立キッチン（K）」の開口面数もそれぞ れ数えている。

注21)ここでの総室数には「公室 (LD)」と「独立キッチン (K)」を含んでいる。したがって， LLKの場合は 4室，3LDKの場合は5室となる。

注22） 1 室当たり開口面数の「2.0」には,「全ての室に2 面開口」の場合のほか「1面開口室と 3 面開口室の組合せ」などが現実にはあり得る。

\section{考文献}

1) 高田光雄、哄 和夫:大都市における民間分㸞集合住宅の類型化、日本建筑学会計画系論文 集、第426号、pp83-90、1991.8

2) 安枝英俊、高田光雄 : 集合住宅の空間構造に関する基礎的研究、日本建築学会計画系論文

集、第523号、pp117-123、1999.9

3)何友鋒: 國民住宅空間標準の確立、建策学会、1993.3

4) 台北市國民住宅處:國宅四年、1990.12

5)内政部営建署:歴年國民住宅政策及ひ建設文献菓編、1991.3

6) 中華民國建筮師公会全國聯合会:台湾の住宅建筮（1976～1990)、1993.7

7)李隆基、張維銓:國宅社區規割設計参考図集、内政部営建署、1996.1

8) 黄 昇塀: 國民住宅居住空間量之研究一以台北市為例一，台湾文化大学修士論文，1980

9)米 復国 : 居民生活方式与国民住宅内部空間設計準則之建立，台湾大学修士論文，1985

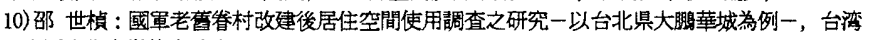
中国文化大学修士論文, 2000

11)陳 紹興 : 高層集合住宅居住環境品質評估方法之研究，台湾中原大学修士論文，1991

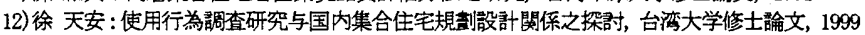

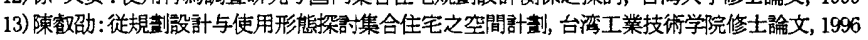
14) 王文安 : 光復後台湾居住空間形態的演変与未来発展之研究，台湾中央大学修士論文, 1986 15) 張哲凡：光復後台湾集合住宅発展過程之研究，台湾成功大学修士論文，1985

16)頼建名 : 国民住宅居住単元空間平面演化之探郡，台滦科技大学修士論文，1995

17)萧恵文 : 台北市都市集合住宅空間形式転化研究，台湾中原大学修士論文，1985 